\title{
ASSESSMENT OF THE IMPACTS OF BAMBOO PROMOTION ON SOIL CONSERVATION AND PEOPLE'S LIVELIHOOD IN GATARAGA SECTOR, MUSANZE DISTRICT, NORTHERN RWANDA
}

*NAHAYO, A., EKISE, I.E., SANKARANARAYANAN, M. and IRANGENEYE, A.

http://dx.doi.org/10.4314/ejesm.v6i5.11

Received 30th May 2013; accepted 16th August 2013

\begin{abstract}
This study aimed at assessing the impacts of Bamboo promotion for soil conservation and improved people's livelihood around Volcanoes National Park (BASOLI/VNP) Project in Gataraga Sector, Musanze District in Northern Province of Rwanda. Problems linked to poverty, bamboo collection and soil erosion are highlighted in Gataraga Sector, the reason why this study was conducted from May to August 2012. Formal, informal interviews and field observation were used to collect data. 41 respondents from Rungu and Mudakama Cells in Gataraga Sector were interviewed. The data was analyzed using Microsoft Office Excel and the Statistical Package for the Social Science (SPSS) 16 using Freidman test, one sample T-Test and paired samples T-Test. Results revealed that the household income and the social services are independent on bamboo production. Farmers got more income after joining Abadacogora cooperative than before the arrival of BASOLI/VNP project ( $t=-$ $6.815, p=0.00$ ). The provision of the health services and better education were the main social services achieved. 34 respondents considered the soil erosion control as the first advantage from bamboo plantation. Cooperatives were considered as an essential pillar in the development process of the members in order to increase household income and improve people's welfare. There is a need to integrate local people into VNP management by increasing awareness on bamboo importance, promote bamboo plantation in tree campaign program and finance micro project for poor people living around VNP.
\end{abstract}

Keywords: Bamboo, soil erosion, local people' livelihood, household income, biodiversity conservation

\section{Introduction}

Bamboo (Sinarundinaria alpina) is a mean of livelihood for a large number of people in most bamboo growing regions of the world (Arun, 2006). It provides considerable environmental benefits in many countries. It is used for ecological purposes such as soil stabilization and erosion control on hill slopes and verges. It is a very important forest plant which is harvested from existing natural forests, plantation and mixed agro forestry systems (Ahlawat et al., 2002). Bamboo is also a multipurpose resource with a number of applications ranging from construction materials, handicrafts, pulp and paper, furniture, fences, edible shoots and animal fodder (UNIDO, 2009). Bamboos are now one of the most valuable and important non wood forest products (FAO, 2007). Therefore, bamboo's importance as both an internationally traded commodity, and as key resource for livelihood development and poverty alleviation, is increasingly being recognized (FAO, 2007). Research studies have proved that bamboo is quite effective in conserving soil erosion in ravines (Kurothe et al., 1997). The bamboo plantation in ravines also provides some indirect benefits including the prevention of soil erosion. The soil conservation effects of bamboo studied at the research farm, in Vasad in India, have shown that the bamboo plantation retains 80-100 per cent of rainwater. This water is either used by the vegetation or recharges the groundwater. The sediment yield is reduced to $1.4 \mathrm{t} / \mathrm{ha}$ in a high rainfall year, which is $10-20$ times less than an untreated watershed (Kurothe et al., 2002 - 03). Further, the studies conducted at the farm also showed the conservation effect of bamboo plantation on improved soil health over a period of time (Tiwari et al., 1998).

Bamboo promotion for Soil conservation and improved people's livelihood in the surrounding zones of Volcanoes National Park (BASOLI/VNP) is a project implemented by Association Rwandaise des Ecologistes (ARECO) Rwanda Nziza and benefited from a financial support from Greater Virunga 
Transboundary Collaboration (GVTC). To promote soil conservation and improve people's livelihood in the surrounding zones of the Volcanoes National Park, ARECO Rwanda nziza implemented the first phase of BASOLI/VNP from April 2009 to September 2010. The second phase started in October 2010 and was jointly implemented by Rwanda Bamboo Society (RWABASO) and ARECO Rwanda nziza for a period of 8 months. ARECO Rwanda Nziza is a local nonprofit making association founded in 1991 by people concerned with environment degradation in Rwanda. ARECO Rwanda nziza was granted legal entity by the Ministerial decree no 119/05 of 5 April 1992 which was revised by the Ministerial decree no $180 / 11$ of $11^{\text {th }}$ December 2008. Its mission is to promote sustainable development through environmental protection. The association extends its activities all over the country, with a special emphasis on zones with high risk of degradation (mountains, natural forests, wetlands and watersheds). Currently, ARECO Rwanda Nziza activities are based in Musanze, Burera, Gicumbi, Gakenke, Nyabihu, Rutsiro, Ngororero and Karongi Districts in Rwanda. Specifically, the activities carried out are related to the conservation of the Volcanoes National Park and Mukura Forest Reserve. The contribution to the conservation of Volcanoes National Park (VNP) and the restoration of Virunga landscape by ARECO-Rwanda Nziza in partnership with all partners and stakeholders involved took about 35 months (from April 2009 to March 2012) and has been divided into 3 phases including a pilot phase within 18 months, an extension phase within 12 months and a consolidation phase within 5 months. The launching workshop was held in Musanze District on $16^{\text {th }}$ April 2009.

There are three main problems in Gataraga sector: poverty among the population, bamboo over collection and soil erosion. These unfavorable conditions have immediate consequences on VNP resources, and therefore a threat to that forest ecosystem and its biodiversity. Bamboo collection was the major cause of conflict between the VNP conservationists and the surrounding people. Acute shortage and high demand of bamboos for construction, handicraft making, stakes of climbing crops and fuel wood, medicinal plant collection and water collection are illegal activities in VNP. There is also a problem of strong soil erosion along gullies from the VNP which is an important threat to land resources around VNP (ARECO report of Activities, 2009). The reason why ARECO Rwanda Nziza started working with people living around Volcanoes National Park through its project BASOLI/VNP to improve their livelihood and promote bamboo development for soil and biodiversity conservation.

This study is aimed at assessing the impact of BASOLI/VNP Project on the improvement of local communities' livelihood living around Volcanoes National Park, in Gataraga Sector of Musanze District in Rwanda. The results from the present study provided useful information on how the project contributed to the improvement of local communities' livelihood, to soil erosion control and to the biodiversity conservation. The specific objectives to achieve were the following: (1) To assess the contribution of BASOLI/VNP Project to the household income among local people living around VNP; (2) To assess the contribution of BASOLI/VNP to the improvement of social services (education, health care) at the household level among local people living around VNP; (3) To assess the contribution of BASOLI/VNP Project to the soil erosion control and biodiversity conservation around VNP; (4) To assess the contribution of BASOLI/VNP Project to the improvement of capacities of bamboo propagation techniques and processing technologies among local people living around VNP.

Upon the completion of this study, the following hypotheses should be verified: (1) BASOLI/VNP Project has not significantly contributed to the increase of household income from agriculture among local people living around VNP; (2) BASOLI/VNP Project has not significantly contributed to the acquisition of social services (education, health care) at household level among local people living around VNP; (3) BASOLI/VNP Project has not significantly contributed to the maintenance of soil erosion control, and biodiversity conservation around VNP; (4) BASOLI/VNP Project has not significantly contributed to the development and reinforcement of bamboo propagation techniques and processing technologies among local people living around VNP. In achieving these objectives and verifying these hypotheses, detailed information on bamboo promotion is provided as well as its potential contribution to the improvement of local people's livelihood. This information is essential for guiding policies related to bamboo - 
based poverty alleviation intervention. Moreover, given the general lack of information on the subject, this paper will also contribute towards understanding the wider issues of bamboo plantation and forest - related development challenges in Rwanda.

\section{Material and Methods \\ Study Area}

The study area was Gataraga Sector situated in Musanze District of the Northern Province. It is subdivided into four cells namely Murango, Rungu, Mudakama and Rubindi. The administrative borders of Gataraga Sector are made up as follows: The Northern border is formed by Volcanoes National Park (VNP). The geographical coordinates of VNP are: (1 ${ }^{\circ} 21^{\prime}$ $10^{\circ} 35^{\prime}$ South, $29^{\circ} 22^{\prime}-29^{\circ} 44^{\prime}$ East). Its length is about $40 \mathrm{~km}$ and its width varies from $8 \mathrm{~km}$ to $10 \mathrm{~km}$. The interface of VNP with its local population is about $60 \mathrm{~km}$. The surface area of the park is about $125 \mathrm{~km}^{2}$. The altitude varies from $2400 \mathrm{~m}$ to $4500 \mathrm{~m}$, the highest being the top of Karisimbi with $4507 \mathrm{~m}$. The Western border is Nyabihu Sector; the Southern border is Busogo Sector and Eastern border is Shingiro Sector.

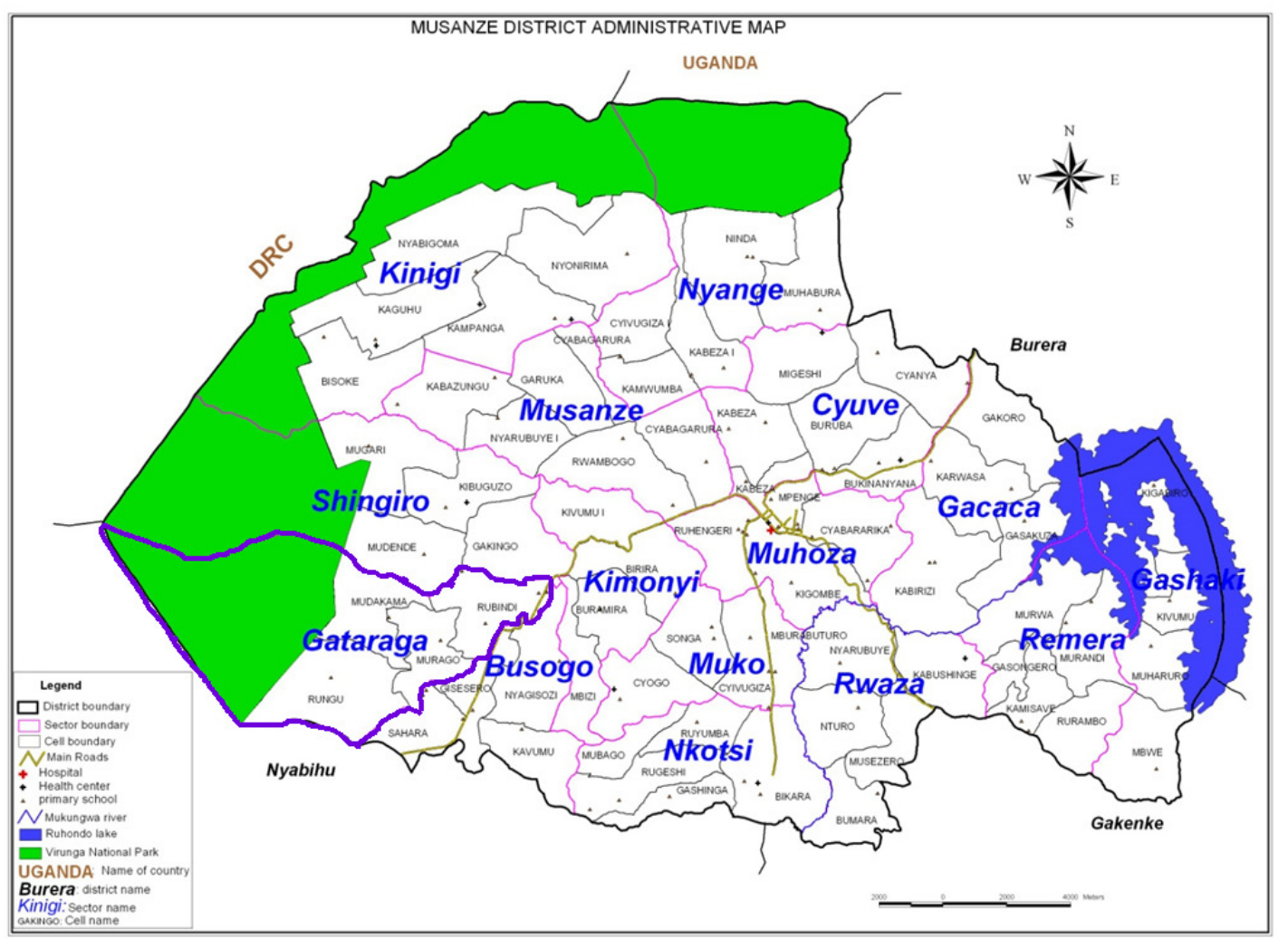

Figure 1 Map of Musanze District showing Gataraga sector

\section{Methodology}

The survey was conducted in one Cooperative (Abadacogora) that worked together with BASOLI/VNP Project in the area from 2009 to 2012. The project established one demonstrative and learning nursery in Gataraga Sector of Musanze District and grouped together the farmers of two Cells (Mudakama and Rungu), the reason why two Cells were chosen among four Cells of Gataraga Sector. Abadacogora Cooperative groups at least one hundred and six farmers working for soil erosion control and biodiversity conservation. Therefore, a sample size of forty one farmers was considered and interviewed. The sample size $n$ was taken according to (Bouchard, 1990) formula: 
No: sample size of finished universe.

$\mathrm{n}=\frac{\mathrm{NNo}}{1+\frac{\mathrm{No}}{\mathrm{N}}}=\frac{\mathrm{NNo}}{\mathrm{N}-\mathrm{Ne}}$

No $=(\operatorname{ta})^{2} \times \frac{\boldsymbol{F}(1-F)}{(\boldsymbol{D})^{2}}$ where:
$\mathrm{P}$ : frequency estimated of $\mathrm{n}$ height.

$\partial$ : error margin.

$\mathrm{t} \partial$ : quantity of order.

$\mathrm{N}$ : universal size.

$\mathrm{n}$ : size of sample

Error taken is $10 \%$ and retained to the more favorable case where $\mathrm{P}=0.5$, and $\mathrm{t} \partial=1.65$

Table 4 Distribution of surveyed farmers

\begin{tabular}{lllcc}
\hline Sector & Cells & Cooperative & Total number of & Members \\
members & & interviewed \\
\hline Gataraga & Mudakama & & 60 & 21 \\
& Rungu & Abadacogora & 46 & 20 \\
Total & & 106 & 41 \\
\hline
\end{tabular}

Data was collected from farmers grouped in Abadacogora Cooperative through formal and informal interviews. Open-ended and closedended questions were asked. Prior to the interview, a pre-testing technique was also used in order to adjust the questionnaire and inform the respondents of the survey. A simple random selection method was used to get 41 respondents from a population of 106 farmers. Gataraga sector was purposively chosen.

The questions were divided into the following four sections:

Sources of income of local people living around VNP;

Impact of BASOLI/VNP Project on the acquisition of social services at household level among local people living around VNP ;

Impact of BASOLI/VNP Project on soil erosion control and biodiversity conservation among local people living around VNP; and

Capacities of bamboo propagation techniques and processing technologies among local people living around VNP.

After collecting data, the analysis was done through the use of Statistical Package for the Social Sciences (SPSS) version 16. Paired samples T-test, Freidman test and one sample TTest were used. The paired t- test procedure compares the means of two variables for a single group. It computes the differences between values of the two variables for each case and tests whether the average differs from 0 . The Freidman test is the non parametric test equivalent of a simple repeated measures design or a two-way analysis of variance with one observation per cell. One sample T-test allows us to test whether a sample median differs significantly from a hypothesized value. A chisquare goodness of fit test allows us to test whether the observed proportions for a categorical variable differ from hypothesized proportions.

\section{Results and Discussion}

Source of income among local people living around VNP

The main activities done by Abadacogora Cooperative members Abadacogora Cooperative is the main source of income amongst respondents. The figure 2 shows different income generating activities carried out by Abadacogora Cooperative.

As shown in figure 2 , the main income generating activities carried out by Abadacogora Cooperative are bamboo plantation with a rate of $18(43.9 \%)$ and $16(39 \%)$ respectively in Mudakama and Rungu Cells, while it is 4 $(9.8 \%)$, and $3(7.3 \%)$ for handcrafts making respectively in Rungu and Mudakama Cells. Abadacogora Cooperative provided local people with cash income without conducting destructive activities in the VNP. 


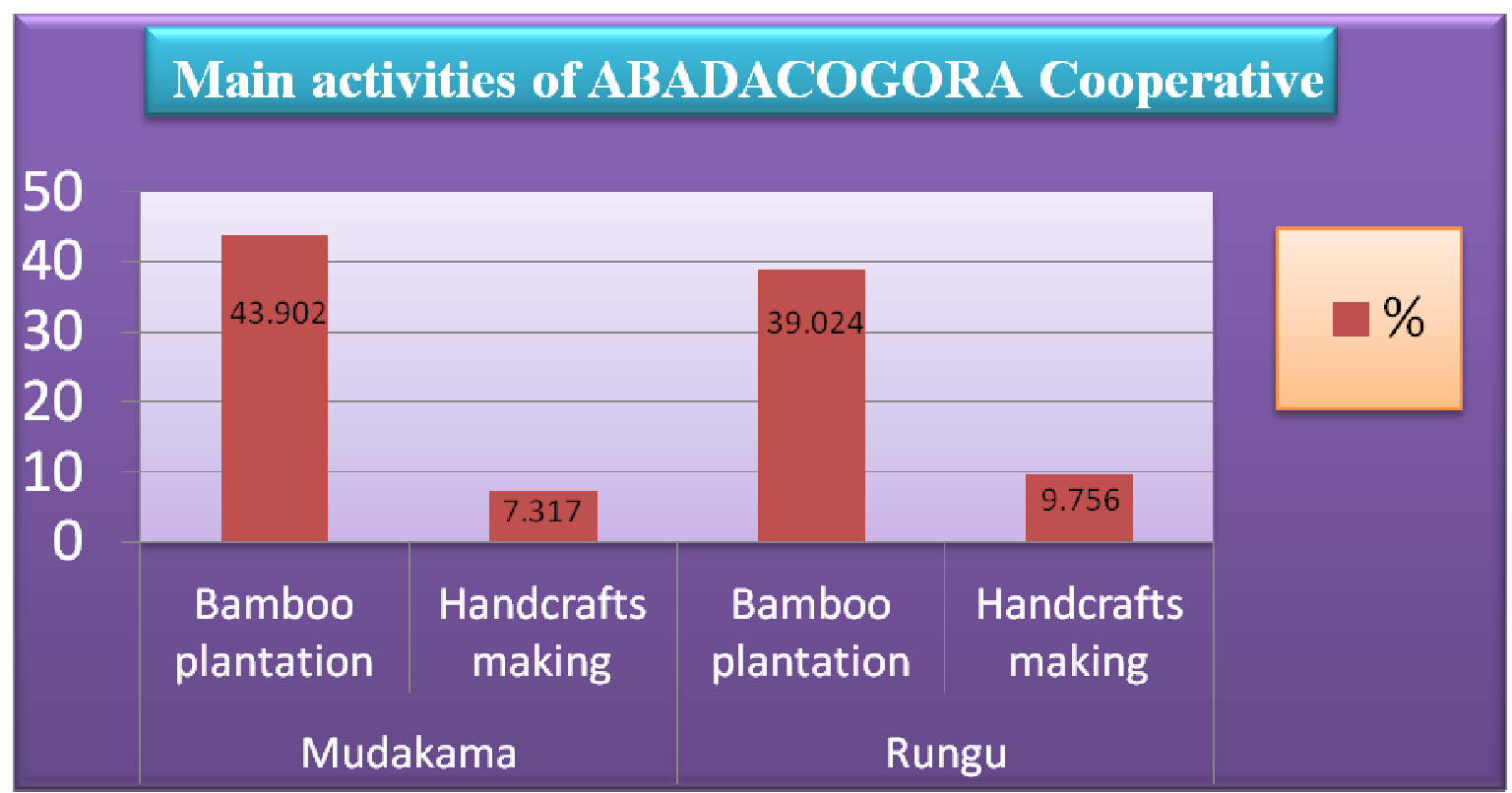

Figure 2 Main activities done by Abadacogora Cooperative members

\section{The Principal Plants Grown}

There are other growing plants that give financial means to Abadacogora Cooperative members so that they can increase the household income. The figure 3 below shows those principal plants grown. It appears from this figure 3 that among the cultures, Irish potatoes ranks first in Mudakama Cell mainly because of its production, with a rate of $12(29.3 \%)$, but it is $6(14.6 \%)$ in Rungu Cell. Maize takes the first place in Rungu Cell with $8(19.5 \%)$, but it is 5 $(12.2 \%)$ in Mudakama Cell. Beans is 4 (9.8\%), 1 (2.4\%) respectively in Rungu and Mudakama Cells, while $3(7.3 \%)$ and $2(4.9 \%)$ represent vegetables in Mudakama and Rungu Cells.

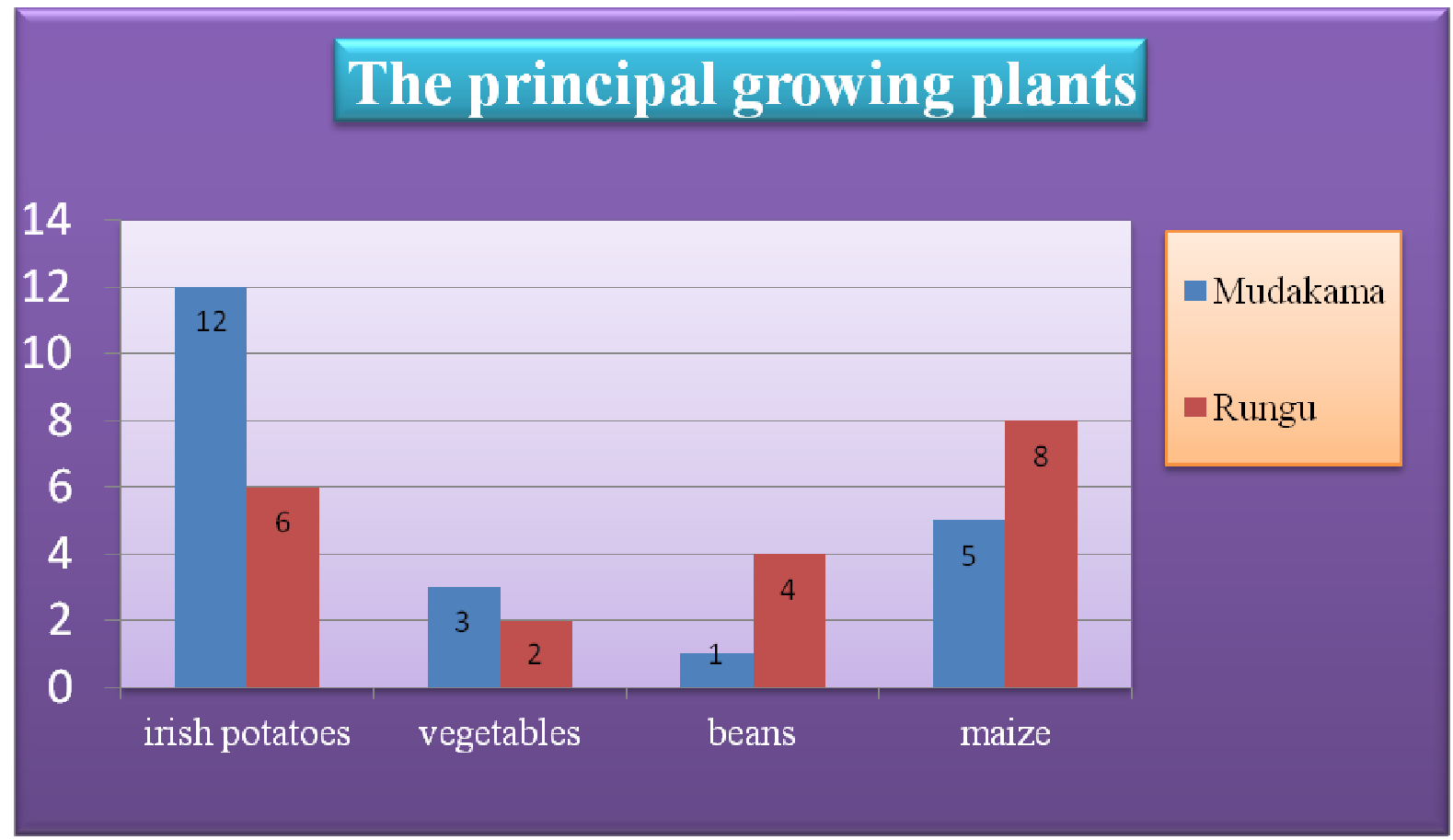

Figure 3 The principal plants grown 
Annual income before and after joining the Cooperative

Before the creation of Abadacogora Cooperative, the majority of respondents were poor with lower revenue which gives logically explanation to their lower annual income. After creation of Abadacogora Cooperative, there has been a remarkable positive change concerning the annual income earned by Cooperative members. Abadacogora Cooperative provides small but significant source of income, particularly for women or families that do not have access to agricultural inputs and other basic needs. Table 2 shows that the mean of annual income after joining the cooperative (2.56) is greater than the mean of annual income before joining the cooperative (1.37).

These results indicate that the mean of annual income before is not statistically significantly different from the mean of annual income after joining the cooperative $(\mathrm{t}=-6.815$, $\mathrm{p}=0.00)$. BASOLI/VNP project has contributed to the increase of household income among local people living around VNP. The annual income after being grouped in Abadacogora Cooperative has increased from 200,000 Rwf to over 400,000Rwf per year. Cooperative constitutes an essential pillar in the development process of the members by increasing the household income therefore enhancing people's livelihood and social welfare. Since 1995, in Lin'an (P.R.China), the bamboo shoot has become the most important source of cash income for villagers. Bamboo shoots also serve as an important source of vegetable. It has become the financial basis for new houses construction $(90 \%)$, children's education $(80 \%)$, industrial investment $(80 \%)$ as well as the purchasing of durable consumables $(85 \%)$. The household possession rate of some common electrical appliances is Color TV 94.9\%; Washing machine 84.6\%; Telephone 96.2\%; Refrigerator 75.6\%; Motor car 87.2\%; Air conditioner 9\%; Car 7\%; Computer 4\% (Zhaohua and Yang, 2003)

Table 2 Paired samples T- test on annual income before and after joining Abadacogora cooperatives

\begin{tabular}{|l|l|l|l|l|l|}
\hline & & Mean & $\mathrm{N}$ & $\begin{array}{l}\text { Standard } \\
\text { deviation }\end{array}$ & Standard Error Mean \\
\hline Pair 1 & $\begin{array}{l}\text { Annual income before } \\
\text { joining the cooperative }\end{array}$ & 1.37 & 41 & 0.829 & 0.130 \\
\cline { 2 - 6 } & $\begin{array}{l}\text { Annual income after joining } \\
\text { the cooperative }\end{array}$ & 2.56 & 41 & 0.867 & 0.135 \\
\hline
\end{tabular}

Table 3 Paired samples test on annual income before and after joining the cooperative

\begin{tabular}{|l|l|l|l|l|l|l|}
\hline Pair 1 & \multicolumn{2}{|l|}{ Paired Differences } & t & df & Sig. (2-tailed) \\
\hline $\begin{array}{l}\text { Annual income before joining the } \\
\text { cooperative - Annual income after joining } \\
\text { the cooperative }\end{array}$ & Mean & $\begin{array}{l}\text { Std. } \\
\text { Deviation }\end{array}$ & $\begin{array}{l}\text { Std. Error } \\
\text { Mean }\end{array}$ & & & \\
\cline { 2 - 9 } & -1.195 & 1.123 & .175 & -6.815 & 40 & 0.000 \\
\hline
\end{tabular}

Impact of BASOLI/VNP project on the acquisition of social services at household level among local people living around VNP Social services afforded by respondents before and after joining the Cooperative

The cooperative is the essential pillar that could contribute to the development of rural population. Actually, life is particularly difficult to handle in rural areas due to lack of other alternative activities than agriculture which may generate revenues. The figure 4 illustrates how the situation of interviewed people before joining Cooperative is and how it is after Abadacogora Cooperative creation.

As shown in the figure 4, the livelihood conditions before joining Abadacogora Cooperative are hardly available or not for the majority of cooperative members. For example, health care means are not available at a rate of $34.1 \%$, and $26.8 \%$ respectively for Mudakama and Rungu Cells whereas education means are not available at a rate of $26.8 \%$, and $36.6 \%$ respectively in Mudakama and Rungu Cells. The results obtained show that BASOLI/VNP project plays a crucial role in the local communities' lives. Therefore, there is no doubt that BASOLI/VNP project has contributed highly in social welfare improvement of people living around VNP. The living situation of the majority of Cooperative members after being grouped in ABADACOGORA cooperative has significantly improved compared to the situation before joining Abadacogora Cooperative. For example, health care means are available at a 
rate of $51.2 \%$, and $48.8 \%$ respectively for Mudakama and Rungu Cells, whereas education means are available at a rate of $48.8 \%, 46.3 \%$ respectively for Mudakama, and Rungu Cells. However, In Nepal, enterprising collectors and farmers who have boosted production of bamboo have not received commensurate increases in profits. Urban market prices have been steadily increasing, but the resultant profit is mostly going to the intermediaries and retailers rather than farmers (INBAR, 1999).

The main development activities achieved due to $\mathrm{BASOLI/VNP}$ project

The Abadacogora Cooperative contributes significantly to the development of rural areas due to the revenues generated from the products made. The figure 5 below shows the main development activities being achieved by Abadacogora members.

The results illustrated in figure 5 show that there are some development activities achieved such as improved agriculture at a rate of 20 $(48.8 \%)$ in both Cells. The agricultural yield increases per unit surface area through the acquisition and application of fertilizers. BASOLI/VNP project allowed access to improved stove at a rate of $8(19.5 \%)$ and 7 (17.1\%) respectively in Rungu and Mudakama Cells. The cattle is purchased at a rate of 4 $(9.8 \%)$ in Mudakama Cell while it is $2(4.9 \%)$ in Rungu Cell.

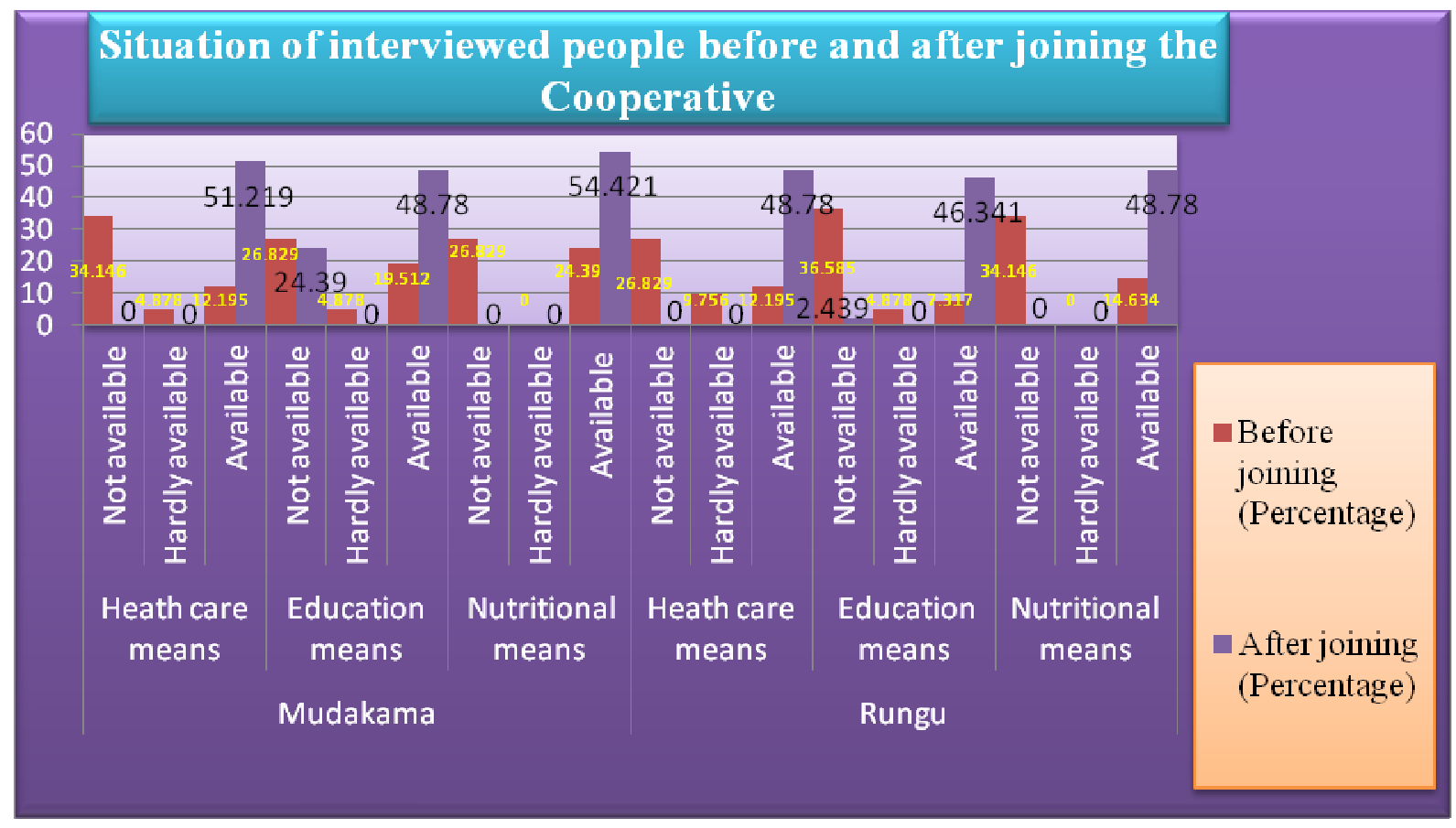

Figure 4 Situation of respondents before and after being grouped in Abadacogora Cooperative

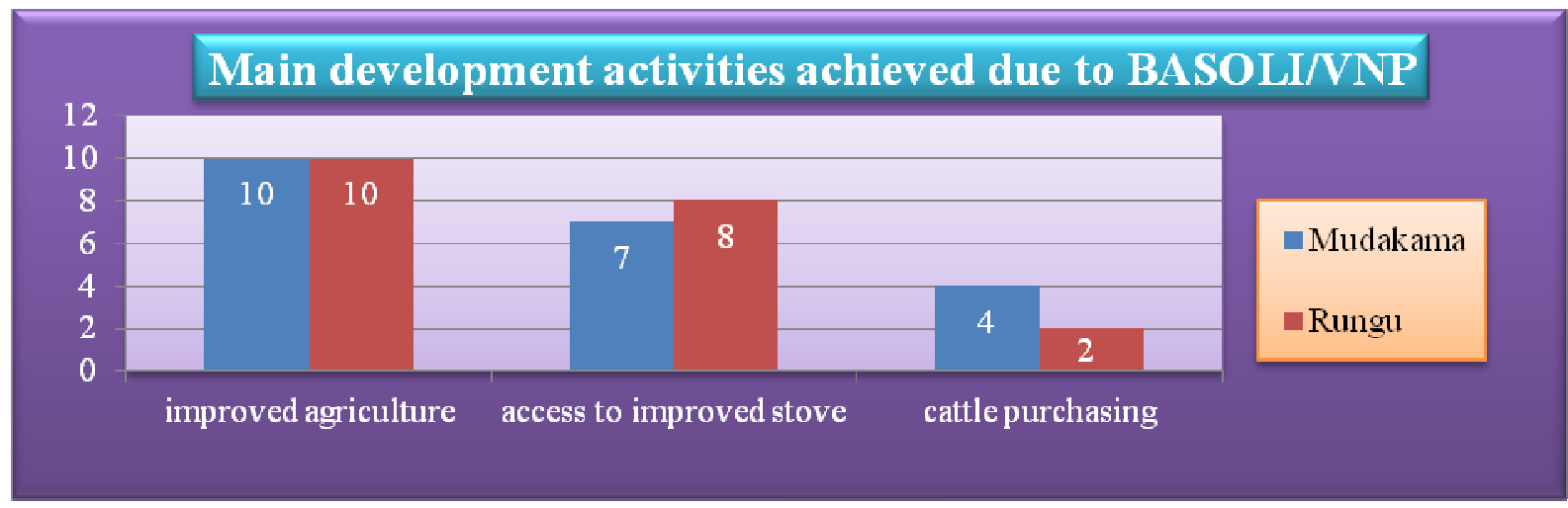

Figure 5 Main development activities achieved due to BASOLI/VNP project 
Impact of BASOLI/VNP project on soil erosion control and biodiversity conservation around VNP Advantages of Bamboo plantation

The following table 4 below indicates the major advantages of bamboo plantation.

Table 4 Advantages of bamboo plantation

\begin{tabular}{lll}
\hline Advantages & Mean rank & Test statistics \\
\hline Soil erosion control & 1.26 & N=41 \\
Biodiversity Conservation & 2.32 & Chi-Square=(58.562) \\
& & Df=2 \\
Asymp. Sig. 0.000 \\
Medical uses & 2.43 & \\
\hline
\end{tabular}

Table 4 shows that the soil erosion is viewed as the first advantage for bamboo plantation with 34 (1.26 mean rank) followed by biodiversity conservation with mean rank of 2.32 and medical uses is the last advantage with 2 (2.43) of mean rank. Based on the Friedman statistical test with p-value of 0.00 at significance level 0.05 , there is a statistical significant difference between the advantages of bamboo plantation ( $\mathrm{p}$ value $<0.05$ ). Therefore, BASOLI/VNP project has contributed to the maintenance of soil erosion control and biodiversity conservation around VNP.

\section{Constraints Related to Bamboo Plantation}

The different constraints related to bamboo plantation are presented in figure 6and it shows that $10(24.4 \%)$ and $4(9.8 \%)$ of respondents respectively in Rungu and Mudakama Cells said that the shortage of land is the problem that they have, while $12(29.2 \%)$, and $6(14.6 \%)$ of respondents respectively in Mudakama and Rungu Cells said that the lack of seedlings remains the biggest problem that they have because they must buy them. If they get sufficient seedlings and enough plots of land, they can produce more bamboo, and therefore, higher income can be generated.

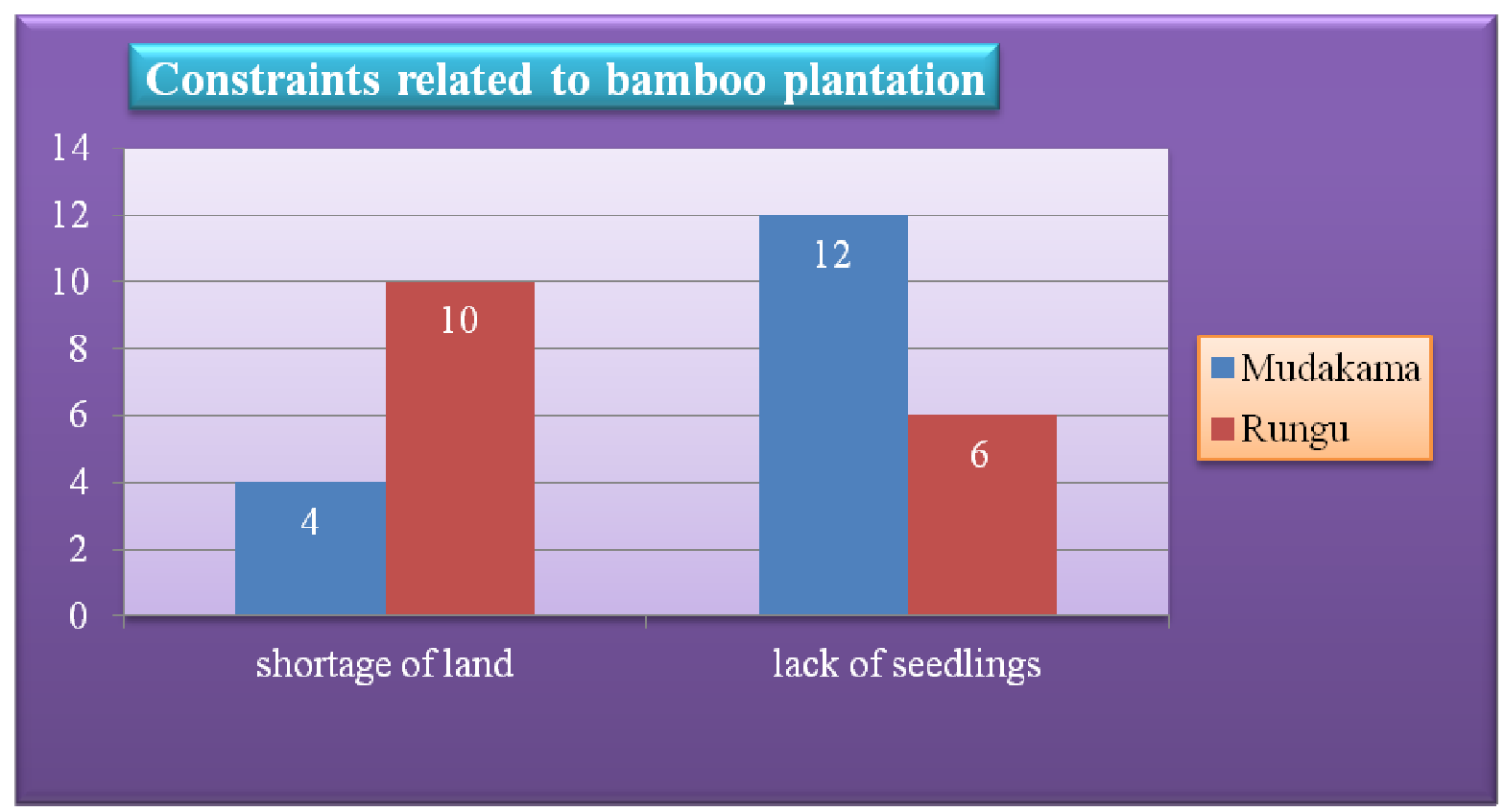

Figure 6 Constraints related to bamboo plantation

\section{Reduction of Illegal Activities}

Most of people surrounding VNP are largely poor farmers who depend on subsistence agriculture and forest resources. Actually, they use a diversity of bamboo products to meet their daily basic needs. This has negative impact on the resources conservation particularly on the VNP resources.

Nineteen respondents (46.3\%), and 15 (36.6\%) respectively in Mudakama and Rungu Cells said that many illegal activities such as uncontrolled harvest of forest resources, 
poaching and bush fire have been reduced compared to the situation before the arrival of BASOLI /VNP project. 5 (12.2\%), and 2 (4.9\%) of respondents respectively in Rungu and Mudakama Cells said that illegal activities have not been reduced totally. Most of respondents were doing illegal activities in VNP and they explained that if they get substantial income from bamboo, they may not do any illegal activity in VNP and confirmed that bamboo exploitation is one way that could ensure sustainable forest management.

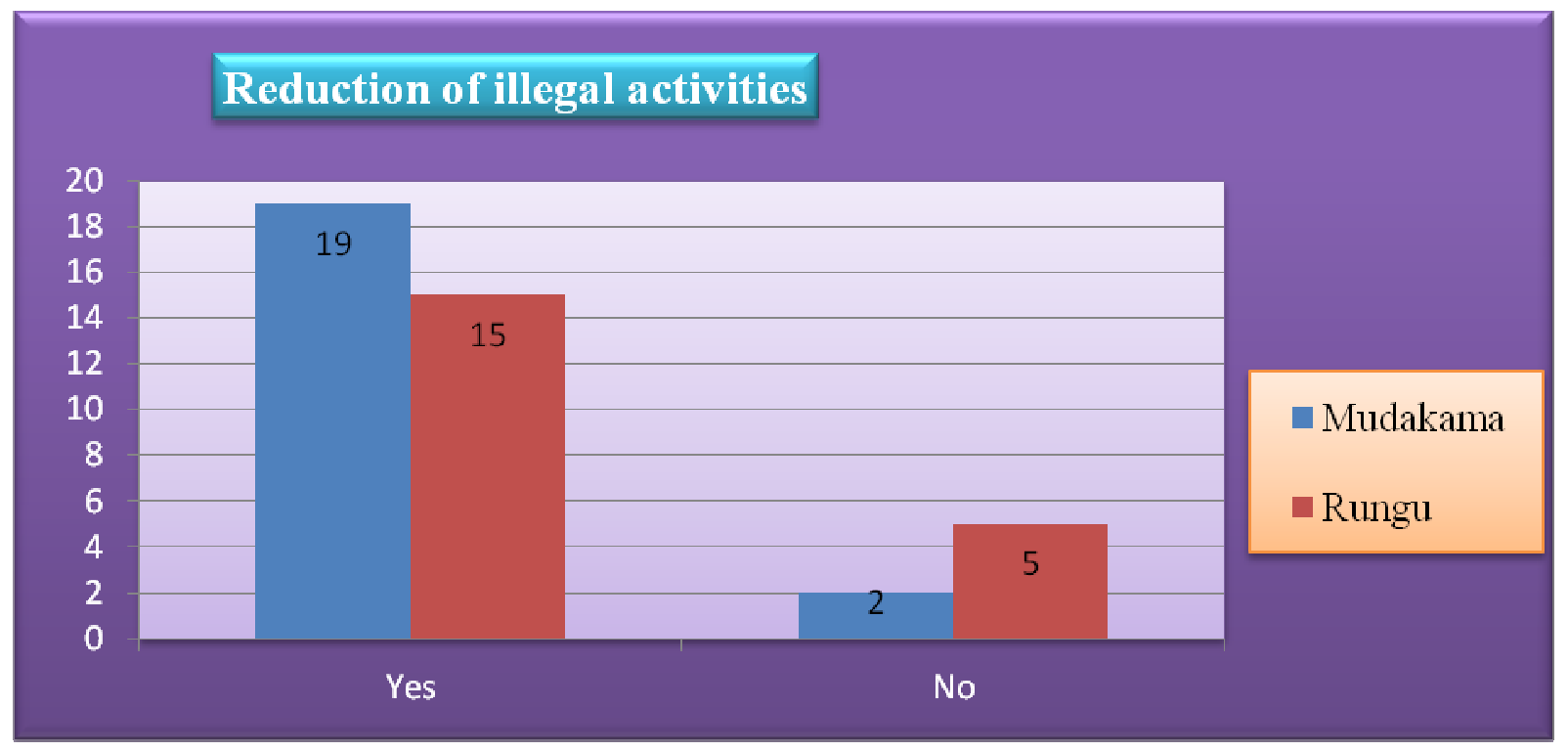

Figure 7 Reduction of illegal activities

Capacities of bamboo propagation techniques and processing technologies among local people living around VNP

\section{Bamboo propagation techniques and processing technologies}

The table 5 indicates the capacities of interviewed people on bamboo propagation techniques and processing technologies.

Table 5: Statistical test on Bamboo propagation techniques and processing technologies

\begin{tabular}{|l|l|l|l|l|}
\hline \multirow{2}{*}{} & \multicolumn{4}{l|}{ Test Value $=0$} \\
\cline { 2 - 5 } & $\mathrm{t}$ & Df & Sig. (2-tailed) & Mean Difference \\
\hline Techniques & 16.073 & 40 & .000 & 1.878 \\
\hline Technology & 19.678 & 40 & .000 & 1.171 \\
\hline
\end{tabular}

The mean values of the technique and technology for this particular sample of farmers are 16.073 and 19.678 which are statistically significantly different ( $\mathrm{p}$ value is 0.00 which is less than 0.05). This means that BASOLI project has contributed to the development and reinforcement of bamboo propagation techniques and processing technologies among local people living around VNP. Therefore, the respondents prefer to use the whole Culm method because it has many advantages as the success and survival rate are higher than the survival rate of other methods and the members of the cooperative that know processing technologies have to train others who are unable to make different materials so that they can produce not only for Rwandan market but also for other parts of the world and then continue to increase their income. In Nepal, the commonest propagation methods used are natural regeneration and the traditional use of rhizome cuttings. Furthermore, farmers also know about the other methods of planting like culm cuttings and seed propagation which are more technical and successful methods of bamboo propagation. However, local farmers lack knowledge about the improved methods of bamboo plantation. They have experienced that the success rate of propagation 
by rhizome cuttings is very less beneficial as compared to culm cuttings and seed propagation (Ghimire, 2008).

\section{Conclusion}

BASOLI/VNP project constitutes an essential pillar in a development process of local communities' livelihood living around VNP. The current study was aiming at assessing the impacts of BASOLI/VNP project on the improvement of local communities' livelihood in Gataraga Sector, Musanze District, Northern Rwanda. Bamboo plantation done by Abadacogora Cooperative is an effective management approach that allows local communities to improve their livelihood in a sustainable way, acquire social services while contributing to the soil erosion control and biodiversity conservation. The main income generating activities carried out by Abadacogora Cooperative are bamboo plantation and handcrafts making. The living standards for the majority of Cooperative members after being grouped has significantly improved compared to the situation before. BASOLI/VNP project has put in place different strategic plans for the well being of people living around VNP. It has been mentioned that bamboo plantation have had an impact in changing behavior towards increasing level of livelihood, soil erosion control, biodiversity conservation, increasing capacities in bamboo propagation techniques and processing technologies. There is a need to integrate local people into VNP management by increasing awareness on bamboo importance, integrating bamboo in tree campaign program and financing micro project from the poorest people living around VNP.

\section{Acknowledgement}

The authors acknowledge the technical support provided by the Higher Institute of Agriculture and Animal Husbandry (ISAE) - Busogo for the completion of this study.

\section{References}

Ahlawat, S.P, Haridasan, K. and Hedge, S.N. (2002), Field manure for propagation of bamboo in North East India, SFRI Information Bulletin No. 14, 18p, India.
ARECO Rwanda nziza report of Activities, August 2009, 2-3 p, Kigali, Rwanda.

Arun (2006), Bamboo Nursery, Culm Cutting Method, CIBART/INBAR/IFAD. Maharashtra, India. $1-7 \mathrm{p}$

Bouchard, A. (1990), The sample size for a given population, Paper no5. Available on line file:///k:/pdf\%20documents/sampling \%28statist ics\%29.htm.

FAO. (2007), World bamboo resources: a thematic study prepared in the framework of the Global Forest Resources Assessment 2005. Lobovikov, M., Paudel, S., Piazza, M., Ren, H. and $\mathrm{Wu}$, J. (eds). Non-wood Forest Products \# 18. Food and Agriculture Organisation of the United Nations, Rome.

Ghimire, A. (2008) An Assessment of the Dependency of Farmers on Bamboo Resource for Rural Livelihood in Lalitpur District, Nepal. MSc thesis. Mountain forestry. University of Natural Resources and Applied Life Sciences (BOKU), Vienna, Austria. 113p

International Network for Bamboo and Rattan (INBAR), (1999), Socio-economic Issues and Constraints in the Bamboo and Rattan Sectors: INBAR's Assessment. Working Paper No. 23. ISBN 81-86247-43-2; 32P.

Kurothe, R. S., Batta, R. K. and Sharma, J. P. (1997), Soil erosion map of Gujarat. Indian Journal of Soil Conservation, 25(1), 9-13.

Kurothe, R. S. and Nambiar, K. T. N. (2002-03), Annual Report, Central Soil \& Water Conservation Research \& Training Institute, Dehradun.

Tiwari, S. P., Patel, A. P. and Singh, H. B. (1998), Soil health as affected by conservation measures in ravine lands of Gujarat. In: Soil and Water Conservation, Challenges and Opportunities. Eds: L.S. Bhushan, I.P. Abrol and M.S. Rama Mohan Rao. Indian Association of Soil \& Water Conservationists, Dehradun.

UNIDO (2009), Bamboo cultivation manual. Guidelines for cultivating Ethiopian highland bamboo. Eastern Africa bamboo project, Ethiopia-Kenya, 65p.

Zhaohua, Z. and Yang, E. (2003), Impact Assessment of Bamboo Shoot on Poverty Reduction in Lin'an, China. International Network for Bamboo and Rattan. 30P 